Revista Eletrônica do Mestrado em Educação Ambiental

\title{
O espelho mágico das resistências: das fabulações cotidianas à apoteose do carnaval
}

\author{
Vinícius Leite Reis ${ }^{1}$ \\ Universidade do Estado do Rio do Janeiro \\ https://orcid.org/0000-0002-8574-5321 \\ Simone Gomes da Costa ${ }^{2}$ \\ Universidade do Estado do Rio do Janeiro \\ https://orcid.org/0000-0001-7636-3340 \\ Maria da Conceição Silva Soares ${ }^{3}$ \\ Universidade do Estado do Rio do Janeiro \\ https://orcid.org/0000-0001-6846-9604
}

Resumo: Por entendermos que o real é fabricado por práticas cotidianas (CERTEAU, 2014) é que buscamos discutir neste trabalho interfaces relacionadas à fabulação, tal qual como a pensamos, produzida em ato. Para isso, trouxemos para este trabalho um recorte da pesquisa intitulada Professoras em devir: Fabulações imagéticas de si, problematizações do feminino e implicações para a docência. A nós, nos interessa o bioempoderamento, as táticas dos praticantes (CERTEAU, 2014) que tensionam as estratégias do biopoder. Apresentamos o carnaval da cidade do Rio como resultado de um processo histórico de resistência. A potência do falso inscrita nos corpos, através de gestos, performatividade e discursos, nos permite criar mundos, territórios existenciais onde a resistência é cotidiana, táticas de sobrevivência, subversão, conveniência. O carnaval é a metalinguagem do real.

Palavras-chave: Cotidiano. Fabulação. Metalinguagem. Gênero e sexualidade.

\footnotetext{
${ }^{1}$ Doutorando no ProPEd - Programa de Pós Graduação em Educação da UERJ. Mestre em Educação (UERJ). Graduado em Comunicação Social - Radialismo (FAESA) e membro do Grupo de Pesquisa CNPq "Currículos, Audiovisuais e Diferença". e-mail: viniciusreiswork@gmail.com

${ }^{2}$ Doutora em educação pelo Programa de pós-graduação em Educação PROPED-UERJ. Mestre em educação - PROPEDUERJ, especialista em gênero, sexualidade e direitos humanos pelo IMS-UERJ. Graduação em Pedagoga (UERJ). Professora das séries iniciais do Ensino Fundamental da cidade do Rio de Janeiro, membro do Grupo de Pesquisa CNPq "Currículos, Audiovisuais e Diferença". e-mail: si25.costa@gmail.com

${ }^{3}$ Pós-doutora em Educação (UERJ), professora associada da Universidade do Estado do Rio de Janeiro-UERJ e coordenadora do Grupo de Pesquisa CNPq “Currículos, Audiovisuais e Diferença”. e-mail: ceicavix @ gmail.com
}

Rev. Eletrônica Mestr. Educ. Ambient. Rio Grande, Dossiê temático "Imagens: resistências e criações cotidianas", p.327-346, jun. 2020. E-ISSN 1517-1256 


\title{
El espejo mágico de laresistencia: desde lasfabulacionescotidianas hastalaapoteosisdel carnaval
}

Resumen: Debido a que entendemos que lo real es fabricado por prácticas cotidianas (CERTEAU, 2014), buscamos discutir en este trabajolas interfaces relacionadas con la fabulación, tal como lo pensamos, producidas en acción. Para esto, trajimos a este trabajo una sección delLa investigación titulada Maestros endevenir: fabulaciones imaginarias del yo, problematizaciones de lo femenino e implicaciones para la enseñanza. Estamos interesados en el bioempoderamiento, las tácticas de los profesionales (CERTEAU, 2014) que tensan las estratégias del biopoder. Presentamos el carnaval de la ciudad de Río como resultado de un proceso histórico de resistencia. El poder de lo falso inscrito en los cuerpos, a través de gestos, performatividad y discurso, nos permite crear mundos, territórios existenciales donde la resistencia es diaria, tácticas de supervivencia, subversión, conveniencia. El carnaval es el metalenguaje de lo real.

Palabras clave: vida cotidiana. Fabulación. Metalenguaje. Género y sexualidad.

\section{The magicmirrorofresistance: fromeverydayfabulationstotheapotheosisofcarnival}

\begin{abstract}
Because weunder stand that the real is manufactured by everyday practices (CERTEAU, 2014), weseek to discuss in this work interfaces related to the fabulation, just as wethink it, produced in action. For this, webrought to this work a section of theres earch entitledTeachers in becoming: Imaginary fabulations of the self, problematizations of the feminine and implications for teaching. We are interested in bio-empowerment, the tactics of practitioners (CERTEAU, 2014) thattension the strategies of biopower. We present the carnival of the city of Rio as a result of a historical process of resistance. The Power of the false inscribed on the bodies, through gestures, performativity and discourse, allow sustocreate worlds, existential territories where resistanceis daily, tactics of survival, subversion, convenience. Carnivalis the metalanguage of the real.
\end{abstract}

Keywords: Daily life. Fabulation. Metalanguage. Genderandsexuality.

\section{Introdução}

Espelho Mágico foi ao ar em 1977, às 20 horas, na Rede Globo. Escrita por Lauro César Muniz, a novela abordava "o dia-a-dia, o sucesso e os conflitos vividos por profissionais ligados aos meios de comunicação: atores, diretores, autores e jornalistas" (DICIONÁRIO DA REDE GLOBO, 2003, p.76). O eixo central da trama eram os bastidores de Coquetel de Amor, uma novela fictícia inserida na trama da novela. Espelho Mágico era a novela da novela. Durante sete meses, aproximadamente, o público acompanhou as histórias dos bastidores de uma novela que só existia na ficção e o drama de seus personagens. Foram 150 capítulos de uma novela que contava a história de outra novela.Uma fabulação da fabulação, a história da história, a ficção da ficção, o cotidiano do cotidiano.

Veja bem, quando dois espelhos são colocados lado a lado, paralelamente, um de frente para o outro, nossa imagem refletida se multiplica ao infinito.O mesmo efeito ótico 
ocorre quando apontamos a lente de uma câmera para a tela onde a imagem que está sendo capturada é exibida/projetada. Em cascata, a imagem se projeta ao infinito. É a imagem dentro da imagem refletida.

Trouxemos estes dois exemplos para pensarmos a reflexão do espelho (fenômeno ótico) e a metalinguagem (da novela) como processos de fabulação de corpos e subjetividades nos 'espaçostempos ${ }^{4}$ de cotidianos que podem ser audiovisualizados (KILLP, 2012), mediados pelo digital em rede, criando mundos e existências que ressignificam o real e produzem conhecimentos, 'saberesfazeres' outros que, por fim, criam resistências, pensadas aqui como outros modos de existência para além das rostificações, formatações e codificações.

No audiovisual, tradicionalmente, busca-se uma distinção entre o que é ficção e o que é documentário.A ficção é entendida como o 'espaçotempo' da criação, invenção, enquanto o documentário é entendido como o 'espaçotempo' do "real", verdadeiro. Entretanto, ambos são 'espaçostempos' de fabulação. Talvez, em um a fabulação seja mais perceptível que no outro, mais assumida que no outro, mas ambos produzem realidade, são produtoras daquilo que chamamos de real e que pretendemos descrever.

E se o "real" não fosse tão real assim?

Trouxemos o exemplo da telenovela, audiovisual cuja produção do Brasil é líder em excelência, para falar de metalinguagem, um recurso em que a própria linguagem é utilizada como tema e conteúdo daquilo que está sendo escrito, filmado, cantado, narrado, performado. As linguagens, assim como as tecnologias, são criadoras de mundos e não se cansam de inventar outros mundos e de reinventar a si mesmas.

Buscamos, sem sucesso, separar os mundos. O mundo da ficção, o mundo do documentário, o meu mundo, o seu mundo, o mundo das artes, o mundo da moda, o mundo do outro, o nosso mundo. Tudo em vão!

As linguagens exercem uma função fabuladora (DELEUZE, 1985). Mesmo quando se propõem a descrever ou representar o real, acabam, por fim,por fabricá-lo (CERTEAU, 2011).

O real é fabricado cotidianamente, seja pela matéria do jornal ou da TV, seja por nós mesmos, com nossos corpos. Habitamos um mundo real que é fabulado por eles, por

\footnotetext{
4 "Esses vários termos e tantos outros que ainda aparecerão neste texto, estão assim grafados porque, há muito, percebemos que as dicotomias necessárias à criação das ciências na Modernidade têm significado limites ao que precisamos criar na corrente de pesquisa a que pertencemos. Com isso, passamos a grafar deste modo os termos de dicotomias herdadas: juntos, em itálico e entre aspas. Estas últimas foram acrescentadas com vistas a deixar claro aos revisores/as de textos que é assim que estes termos precisam aparecer”. (ANDRADE et al, 2019, p. 19)
} 
nós, por mim e por você também. A fabulação se dá em ato, práticas cotidianas (CERTEAU, 2014), portanto atuação nos 'espaçostempos' daquilo que chamamos de real: uma sala de aula, na esquina, na praça, na igreja, na casa da tia, nas redes sociais ou no sambódromo da Marquês de Sapucaí. É a metalinguagem do real.

Com nossos corpos, habitamos as redes sociais na internet, audiovisualizamos nossa existência no digital em rede. Para tanto, produzimos imagens, fotos e vídeos que são, como no espelho, o reflexo de nós mesmos, ou do que queremos ser, de como queremos nos dar a ver.No digital, existe a possibilidade de dar uma melhoradinha no visual. Os aplicativos de imagem e vídeo para smartfones nos permitem melhorar a cor da foto, mexer no brilho e contraste, fazer uma limpeza de pele, mudar a cor do cabelo ou dos olhos, engordar ou emagrecer, podemos até mudar o fundo, ou seja, estar em Paris sem nunca ter pisado em solo francês. Sim, a fabulação pode ser extrema (macrofabulação), mas outras são menos perceptíveis (microfabulação). A postura da pessoa, por exemplo, se ela está séria ou sorrindo, se está segurando uma taça de chopp ou um suco detox, se está dentro de uma sala de aula ou no bloco de carnaval, enfim, produzem diferentes sentidos, portanto, atuamos em concordância ou discordância com todos estes elementos, fabulando nossas existências. Em outras palavras, atuamos de acordo com nossas conveniências, num devir das imagens e de nós mesmos, personagens reais, quando nos propomos a fabular sobre nós.

Para Certeau, "a conveniência mantém relações muito estreitas com os processos de educação implícitos a todo grupo social" (2013, p. 49), por isso, fazemos uso da mesma em nossos processos de fabulação na vida cotidiana. Certeau ainda complementa,

A conveniência é o gerenciamento simbólico da face pública de cada um de nós desde que nos achamos na rua. A conveniência é simultaneamente o modo pelo qual se é percebido e o meio obrigatório de se permanecer submisso a ela: no fundo, ela exige que se evite toda dissonância no jogo dos comportamentos, e toda ruptura qualitativa na percepção do meio social. Por isso é que se produz comportamentos estereotipados, "pret-àporter" sociais, que têm por função possibilitar o reconhecimento de não importa quem em não importa em que lugar. (2013, p. 49)

Buscamos reconhecimento, inteligibilidade, seja na adoção de um padrão hegemonicamente aceito, ou na dissidência do mesmo. Por isso, pensando com imagens, algumas selfies, como a do espelho da academia, são clássicas. Podemos afirmar então que a selfie, fenômeno das redes sociais mediadas pelo digital, são mais que autorretratos, são também produção de um discurso imagético cuja intenção já foi previamente fabulada, 
inscrita em práticas sociais mais antigas e nas possibilidades do aparelho (como a câmera). Neste caso, também, podemos considerar a tela do smartfone, cuja imagem é captada pela câmera do dispositivo e nela é refletida, como uma espécie de espelho mágico do real, onde a escolha do enquadramento, a postura, o local, o gesto, por fim, produz realidade, com ou sem os efeitos de pós produção dos aplicativos instalados no dispositivo de captura da imagem.

Trata-se para Deleuze e Guattari da produção rostos sobre codificados (apud MARQUES, 2015). Para os autores, um rosto se faz em operações de significação e processos de subjetivação. Conforme Marques (2015, p. 167):

\begin{abstract}
A rostidade se constrói por zonas de frequência, por movimentos de probabilidade: em alguns momentos, as expressões e as conexões que forem rebeldes às significações conformes são neutralizadas; em outros, as expressões e as conexões funcionam como lugar de ressonância, de reforço, selecionando um sentido e deixando-o de acordo com uma realidade dominante. O rosto, continuam os nossos filósofos, não é parte do corpo, a cabeça, a face. Nasce de uma máquina abstrata de rostidade, que o produz por sobrecodificações (DELEUZE e GUATTARI, 2004, p.33 e 35$)$.

O rosto-conceito é porta-voz de escolhas e de elementos organizados. Uma máquina tem o papel de detector de desvianças e de ordenação da normalidade (DELEUZE e GUATTARI, 2004, p.45). O rosto não é um universal. Rosto é política. É uma produção.
\end{abstract}

Se o rosto é uma produção política, somos, para Deleuze e Guattari, capazes de escapar dele, de desfazê-lo, desconstruir as rostificações e dessa forma tornar-se clandestino. “[...] Se o rosto é uma política, desfazer o rosto também o é, engajando devires reais, todo um devir-clandestino." (DELEUZE e GUATTARI, 2004, p.58 apud MARQUES, 2015, p.170). Segundo os autores, podemos buscar novos/outros usos para a máquina-rosto. Trata-se, neste caso, de evitar a busca de um único rosto, dando lugar à multiplicidade.

Se a rostidade resulta de agenciamentos de poder, as fabulações, por outro lado, nos possibilitam problematizar nossos processos de formação e subjetivação, abrindo espaço para a criação de novas estéticas de existência e novas imagens para pensar e praticar a vida em sociedade na sua complexidade e multiplicidade. Dessa forma, correndo pelo centro, brechas e caminhos múltiplos, é possível desenhar outras maneiras de pensar/praticar/atuarmos/dos/com os cotidianos.

Rev. Eletrônica Mestr. Educ. Ambient. Rio Grande, Dossiê temático "Imagens: resistências e criações cotidianas", p.327-346, jun. 2020. E-ISSN 1517-1256 


\section{O corpo fabulado}

Vivemos na era farmacopornogáfica, segundo Preciado. Um tempo onde corpos e subjetividades são produzidos para atender às necessidades de um biocapitalismo que já “não produz coisas, e sim ideias variáveis, órgão vivos, símbolos, desejos, reações químicas e condições de almas". (2018, p. 38)

Aprendemos a viver em sociedade não somente pelos usos que fazemos da conveniência (CERTEAU, 2013), mas também através dos rituais e dos gestos (WULF, 2013) que produzimos miméticamente. São linguagens 'sóciocorporais' que nos legitimam e nos enquadram (BUTLER, 2018) dentro de um determinado corpo social. Wulf nos aponta que

Gestos acompanham a fala, mas também têm sua autonomia, que não está diretamente ligada à fala. [...] Os conteúdos expressos por gestos são com frequência mais intimamente ligados aos sentimentos dos falantes do que a suas declarações verbais. São considerados como uma expressão mais confiável da vida interior da pessoa do que suas palavras, que são mais conscientemente controladas.

Indivíduos, grupos e instituições encenam a vida social. Eles desenvolvem coreografias de comunidades humanas. Essas encenações de corpos, gestos e formas de expressão ritual podem ser lidas como textos e decodificadas. (2013, p. 130)

Gestos são próteses encarnadas, segundo Preciado. Talvez daí a ideia de que sejam mais verossímeis, confiáveis. Não esqueçamos, pois, que os gestos são performados, encenados, e que de acordo com a conveniência podem ser fabulados.Gestos produzem diferenças que podem ser observadas em relação à classe e ao gênero.

O gênero farmacopornográfico não é metáfora nem ideologia; não pode ser reduzido a uma performance: é uma forma de tecnologia política. A certeza de ser homem ou mulher é uma ficção somatopolítica produzida por um conjunto de tecnologias do corpo, técnicas farmacológicas e audiovisuais que determinam e definem o alcance das nossaspotencialidades somáticas e funcionam como próteses de subjetivação. O gênero é um programa operacional capaz de desencadear uma proliferação de percepções sensoriais sob a forma de afetos, desejos, ações, crenças e identidades.Um dos resultados característicos desta tecnologia de gênero é a produção de um saber interior sobre si mesmo, de um sentido do eu sexual que aparece como uma realidade emocional para a consciência. "Sou homem", "Sou mulher","Sou heterossexual", "Sou homossexual","Sou transexual":estas são algumas dasformulações que condensam saberes específicos sobre si mesmo, agindo como núcleos biopolíticos e simbólicos rígidos em torno dos quais é possível aglutinar

Rev. Eletrônica Mestr. Educ. Ambient. Rio Grande, Dossiê temático "Imagens: resistências e criações cotidianas", p.327-346, jun. 2020. E-ISSN 1517-1256 
todo um conjunto de discursos e práticas performativas (PRECIADO, 2018, P. 127)

Preciado amplia a discussão e afirma que "estamos equipados tecnobiopoliticamente para trepar, reproduzir o Corpo Nacional e consumir". (2018, p. 128) É o biocapitalismofarmacopornográfico investindo sobre os corpos todo um conjunto de tecnologias para a formação de sujeitos sexuais generificados. Por isso, pelo caráter artificial da tecnologia, "somos estranhas ficções biopolíticas porque estamos vivos". (2018, p. 129). Entretanto, apesar das tentativas de controle "somos simultaneamente o efeito do regime de poder farmacopornográfico (biopoder) e o potencial para o seu fracasso (bioempoderamento) (2018, p. 129).

A nós, nos interessa o bioempoderamento, as táticas dos praticantes (CERTEAU, 2014) que tensionam as estratégias do biopoder. São as práticas que atuam, a partir de nossas subjetividadescorpos, no dentrofora dos espaçostempos da escola e, consequentemente, suas implicações para a docência.

Por isso, estamos desenvolvendo a pesquisa intitulada Professoras em devir: Fabulações imagéticas de si, problematizações do feminino e implicações para a docência que você vai conhecer agora.

Marques (2015, p. 161) aponta:

A ideia de fabular a formação docente, por exemplo, é um exercício de pesquisar a própria formação. Trata-se de uma escolha com consequências éticas. Aproximar essa escolha da arte, da fotografia, do cinema, por exemplo, pode resultar em pesquisas que bifurcam o fazer artístico também, transformando-as em objetos singulares. Não são monumentos da arte, no sentido deleuziano, mas também não são meros produtos da academia. Constroem-se em uma estética outra de pesquisa.

\section{'Espaçostempos’ de fabulação}

As audiovisualidades, como práticas cotidianas de significação que vão se tornando corriqueiras em nossa sociedade, estão irremediavelmente implicadas na constituição de subjetividades e na tessitura das redes de sentidos e conhecimentos sobre si, sobre os outros e sobre o mundo. Os praticantes das audiovisualidades criam, ainda, com suas operações de ver/ouvir e de dar a ver/ouvir, técnicas, tecnologias, teorias e possibilidades para o audiovisual. (NOLASCO-SILVA et al, 2018, p. 80)

Buscamos em nossa pesquisa realizar, em estúdio, ensaios fotográficos e vídeográficos com estudantes e professoras, nos quais elas decidiram como se darão a ver, 
como querem ser vistas e ouvidas. Assim, através de fabulações imagéticas sobre si, criamos, neste estúdio, 'espaçostempos' para, simultaneamente, interrogar, refuncionalizar, potencializar, esgarçar e alargar esses processos de formação e essas redes de práticas e significações com as estudantes e professoras sobre o feminino, e, dessa forma, por tabela, sobre corpo-genêro-sexualidade.

A formação de professoras, como processo de subjetivação, de invenção de si e de mundo (KASTRUP, 2005, 2007), se tece em rede com o que é aprendido nos diferentes contextos em que se vive (ALVES, 2008, 2010), entre eles o dos usos das mídias, das audiovisalidades praticadas e de suas apropriações.

Entendemos, com Deleuze, que a potência do falso é a força/poder dos corpos, de afetar e de ser afetado, em processos de fabulação onde já não há verdade nem aparência. A potência do falso é a transformação, a metamorfose do verdadeiro. "A verdade não tem que ser alcançada, encontrada nem reproduzida, ela deve ser criada". (1985, p. 2013) Essa é a verdade do cinema para o filósofo que tanto se esforçou para fazer da sétima arte uma forma de pensamento. Pensar com imagens e sons, fabular. Por extensão, entendemos que esta também é a verdade da ciência e da própria vida.

É engraçado pensar minha construção como professora, porque começa no meu ensino médio. Fiz técnico em eletrônica, e já foi um grande desafio ser menina fazendo eletrônica, fazendo exatas. Meu pai nunca gostou dessa ideia de eu ir para exatas, nunca. Ele achava que eu tinha que ser secretária e que meu irmão tinha que ir para eletrônica. E foi o contrário: meu irmão foi pra administração e eu, para a eletrônica. E fui para faculdade com a intenção de fazer engenharia, eletrônica, fazer informática que eu gostava muito. E no meio do caminho encontrei uma pessoa que disse para eu não fazer análise de sistemas, nem informática. Para eu fazer matemática, que eu iria ter um leque muito maior e não iria ter tanta dificuldade como ele teve quando fez análise de sistemas. Aí fiz vestibular para matemática para várias universidades e fui estudar na rural (UFRRJ), pensando na eletrônica, pensando na informática e me descobri professora. 
Figura 1: Fotografias do ensaio da Cristiane

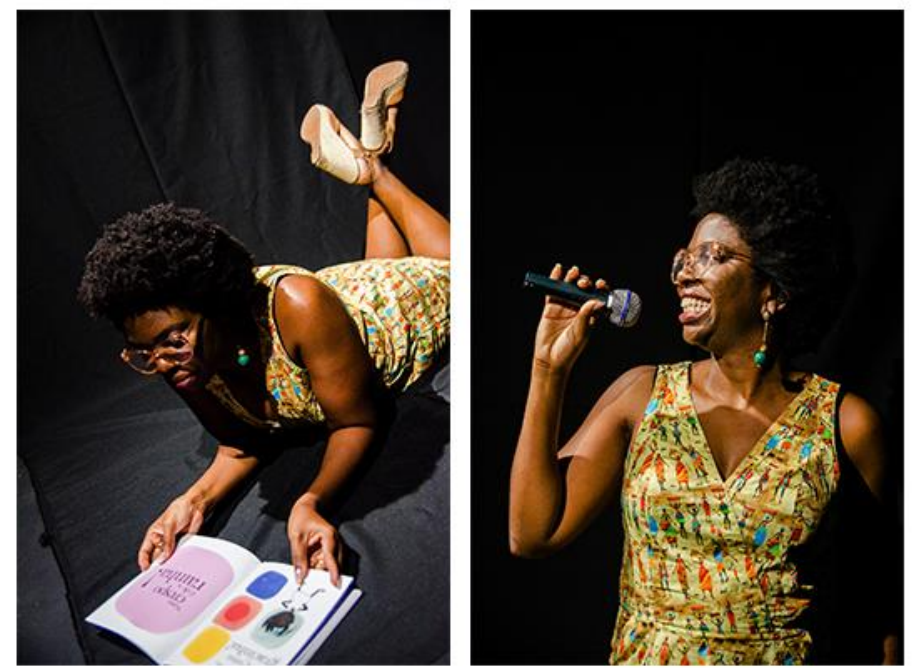

Fotos: Maíra Mello.

Fiz minha matemática. Entrei nas escolas estaduais para dar aula, mas ainda assim ficava uma angustia porque menina, negra, exatas, matemática... então todo um... a coisa da ciência.. e eu queria fazer outras coisas. Trabalhar matemática, mas pensar na questão do empoderamento, na questão do lugar que eu tenho enquanto menina, enquanto mulher, enquanto negra, negra de cabelo black sim. Depois comecei a tirar o henê, comecei a parar de alisar o cabelo e aí eu vi que na matemática eu não ia conseguir, porque vinham várias provas...eu era muito cobrada quanto a isso. Professora de português e matemática são muito cobradas, porque o que dá resultado é isso. Artes, não dá resultado nenhum. E eu falei: cara, vou ter que sair desse caminho. Aí fui por um outro caminho. Descobri na informática educativa um outro jeito de trabalhar e trabalhar com projetos. Hoje, na informática educativa como professora eu já trabalho com projetos. Ainda trabalho com matemática, em parceria com professora de matemática, em parceria com a professora de português, com professor de história, mas com um outro jeito. E pretendo daqui a um tempo, criar um projeto pensando na menina pequena, do fundamental 1 já para ciências, para pesquisa. Eu percebo muitos trabalhos das meninas na ciência, mas no fundamental 2 , ensino médio para lá. Mas e a pequenininha,aquela que entrou no primeiro ano, no segundo ano, e que está ali se construindo enquanto menina, que de repente quer ser como eu: trabalhar com a área de exatas, ser cientista, mas sempre dizem para gente que não é para gente, que não é nosso lugar. Então quero dizer para essa menina pequenininha, de 6/7 anos, que é o lugar dela sim.

Cristiane Marcelino tem 34 anos e é professora de informática educativa. Fez mestrado no ProPEd - Programa de pós graduação em Educação da UERJ, na linha dos cotidianos, pensando na pesquisa com o outro e não para o outro. Trouxe para seu ensaio o livro que ela lê para os filhos (livros com temática negra, crianças negras) e um microfone, 
pois ela canta na igreja. É católica e canta todo domingo na missa. Assim ela se expressa, mostra que é capaz. Cantar significa a liberdade para ela.

A menina negra que queria ser engenheira, queria as "exatas", buscava o saber que uma certa convenção social a negava, a eletrônica era para o irmão, dizia seu pai, como reprodução de tantas vozes que se repetem ao buscar determinar os lugares que as mulheres devem buscar como profissão.

Cristiane depois de formada, já professora de matemática, decide mudar o cabelo, assumir o black, mas a professora de matemática não deveria subverter a uma suposta seriedade que se espera de alguém que ministra uma disciplina tão "importante". Vendo que não haveria espaço em aulas de matemática para propor alternativas para além do conteúdo exigido, em função da enorme cobrança sobre suas aulas, ela decide mudar de campo de atuação onde encontrou a possibilidade de ampliar suas abordagens com a proposta de trabalho com projetos. Visiona um projeto para crianças do primeiro segmento do Ensino Fundamental de incentivo a descoberta da ciência. Ela pretende apresentar as meninas nos seus primeiros anos de escolarização a experiencia do trabalho com as ciências. Cristiane quer apresentar para as crianças de 7/8 anos um leque de possibilidades na experiência científica que não lhe fora oferecido, ela entende que deve transmitir à suas alunas que as ciências exatas e a matemática também são 'saberesfazeres' que podem e devem ser exercidos pelas mulheres, pelas meninas.

Figura 2: Fotografias do ensaio da Paloma
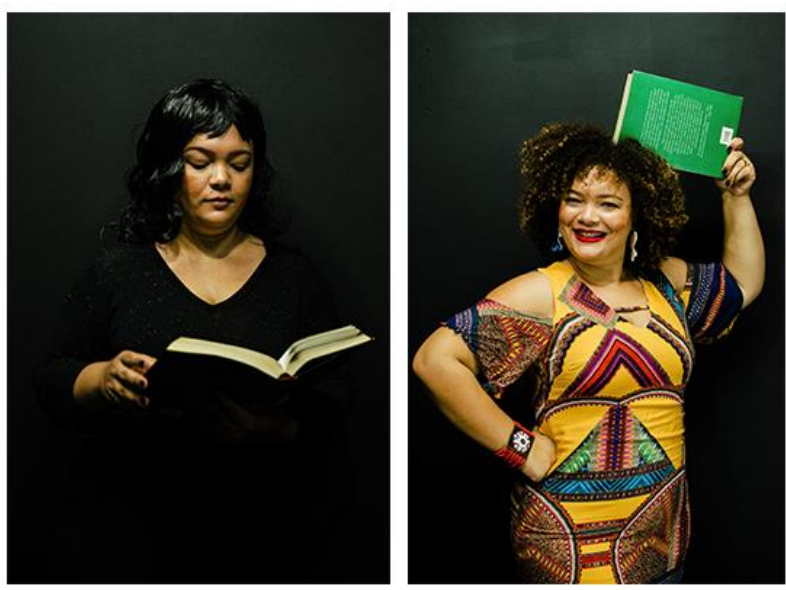

Fotos: Maíra Mello

Inicialmente eu queria ser jornalista, mas acabei entrando na pedagogia, mas também eu tinha contato com crianças, eu gosto muito. [...] Quando eu comecei a faculdade,tinha o cabelo alisado, tinha um estilo diferente, uma forma de pensar diferente. Depois disso, com o tempo eu decidi 
inicialmente por questão estética assumir o cabelo natural. E com o tempo eu fui deixando crescer e tudo mais. É sempre uma questão muito grande estética, porque você fica naquela: "Ah, vou deixar meu cabelo natural, vou ter que cortar curtinho e tudo mais. Como fica sua imagem, né?" Porque ainda mais que a gente tem uma profissão, por mais que você tenha um cabelo todo estragado, mas tá com o cabelo alisado que esteticamente é agradável para todo mundo, tá tudo certo. Mas quando você se assume, você usa algo diferente do que você é, para as pessoas causa um certo impacto. Aí pensei, meu deus, sempre tive problema, sabe, desde novinha, e aí resolveu assumir o natural. Eu fui deixei o cabelo crescer um pouquinho e cortei curtinho. [...] E a partir daquele momento assumi o natural e fui evoluindo tanto esteticamente porque teve a questão do cabelo, mas junto com o cabelo veio questão da culpa, veio a questão da aceitação da identidade e você vai tendo um visão de mundo diferente. É engraçado falar sobre isso, porque a maioria das meninas que eu vi que resolveram então assumir o seu cabelo, tiveram para mim uma mudança social muito grande, de ponto de vista de estudo, de conhecimento de causa. Eu acho muito legal, porque acaba sendo uma integração, né, uma coisa da outra. E depois disso, eu estagiei no município [Escola da rede municipal do Rio de Janeiro] por dois anos, nessa primeira escola, quando eu tive a mudança. [...]Daí eu saí, depois desse estágio eu fui para uma escola particular. E aí, até então, eu tava muito bem resolvida com o cabelo, a estética, mas como é uma escola particular muito tradicional, eu achei que fosse criar problemas nessa escola. Lembro da primeira reunião que eu tive com o diretor, ele viroue falou: que cabelo é esse? É cabelo de férias ou é assim mesmo? E aí na época eu não sabia o que era cabelo de férias, mas já imaginava e falei: não, meu cabelo é assim mesmo. E ele: ah, bonito. Aí falei, acho que ele não gostou muito. Depois eu entendi que o cabelo de férias era porque em todo o momento quando as crianças não estavam na escola os professores iam mais à vontade, com cabelo diferente, roupa diferente. E aí perguntou se meu cabelo era assim naturalmente ou se eu usava o cabelo em momentos que eu não tivesse trabalhando, mas... era meu cabelo. [...]

Eu trabalhei em duas escolas e essa questão do cabelo é sempre muito presente. Pelo menos nas histórias que eu tenho em relação à escola tem uma coisa do cabelo muito conectada. Há pouco tempo eu coloquei trança também e as crianças tem sempre aquela de olhar: "tia, hoje tá horrível seu cabelo. Não gostei desse seu cabelo". Ou de elogiar. E aí eu aproveitei para falar justamente sobre respeito com o corpo do outro com eles. Porque eles queriam tocar, mexiam e opinavam. E eu aproveitei para falar um pouco sobre isso com eles, porque a gente precisa ter respeito com o corpo do outro, com o espaço do outro. A gente não pode tocar no outro, sem perguntar se pode tocar. E aí eu falei: olha, primeiro eu quero que vocês me perguntem se pode tocar no cabelo. Se eu deixar, vocês podem tocar. E que tenha respeito pela minha escolha, né?

Meu nome é Paloma Monteiro. Eu tenho 26 anos, fiz pedagogia na Uerj e trabalho com ensino fundamental, anos iniciais e produção textual. Aqui para este ensaio, eu quis trazer a questão de uma roupa mais formal, toda preta, uma peruca com o cabelo alisado, pra ver que o luto do que eu era antes e que não era o que de fato eu sou e o que eu sou de fato, colorida, com acessórios, turbantes e tudo mais. Para de fato colocar meu antes e depois nessa história.

Rev. Eletrônica Mestr. Educ. Ambient. Rio Grande, Dossiê temático "Imagens: resistências e criações cotidianas", p.327-346, jun. 2020. E-ISSN 1517-1256 
Paloma dispensa maiores apresentações. A força de seu corpo, sua força, está presente nos gestos que escolheu para as fotos assim como na sua narrativa, no seu discurso. "É sua voz que amordaça a opressão" .

Os seus apontamentos representam diferentes situações das legislações do biopoder, principalmente no que diz respeito ao seu cabelo e aos lugares onde esse corpo de cabelo "natural" deve adentrar. Na escola pública o processo fora tranquilo, na particular, ficou um certo sentimento relacionado a rejeição, questionamento, opiniões. $\mathrm{O}$ corpo feminino na escola tem a roupa para dias com crianças e tem outra para dias sem crianças. O cabelo idem. Paloma fala do cabelo natural, se referindo ao não uso de produtos e técnicas que mudam a característica principal de seu cabelo que são os cachos. Aponta também transformações em posicionamento relacionado ao processo de mudanças dos cabelos que está relacionado a outras reflexões e posturas junto a afirmação de um determinado processo identitário. Havia a necessidade de afirmação na medida em que ia descobrindo outros modos de se produzir e produzir mundos.

Figura 3: Fotografias do ensaio da Cátia

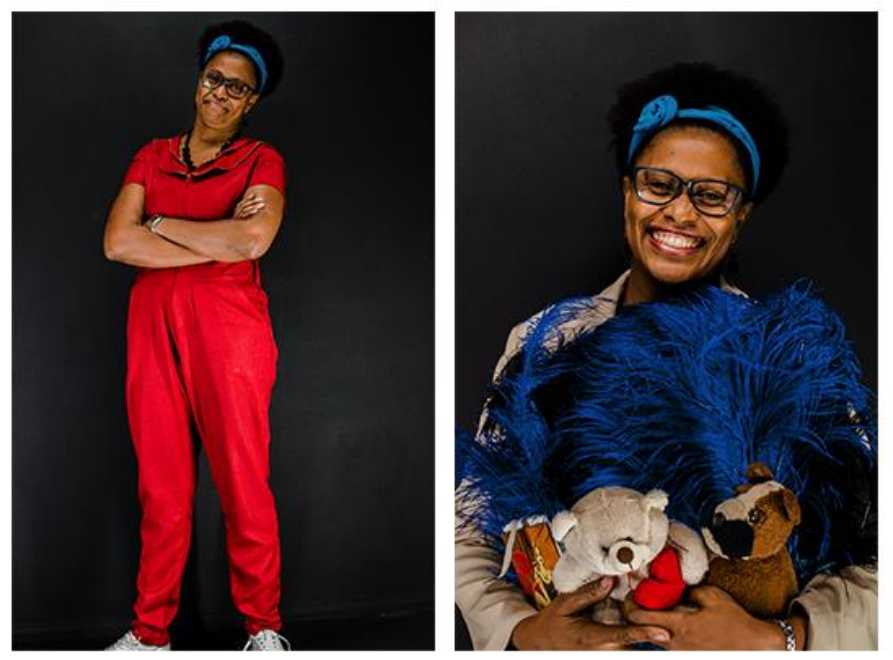

Fotos: Maíra Mello

Antes da nossa conversa começar, Cátia fez questão de citar os versos do sambaenredo $^{6}$ do Paraíso do Tuiuti que, em 2018, levou o vice-campeonato daquele ano, ficando

\footnotetext{
${ }^{5}$ Extraído do samba-enredo da G.R.E.S. Mocidade Independente de Padre Miguel que, em 2020, ficou em terceiro lugar no resultado final do carnaval carioca com "Elza Deuza Soares", ressaltando o talento musical e as lutas da cantora Elza Soares contra o racismo, a censura e o preconceito. Padre Miguel é um bairro localizado na Zona Oeste do Rio de Janeiro. Três dias após a apuração das notas dos jurados, ou seja, durante à noite, no desfile das campeãs que ocorre no sábado seguinte à apuração na Marquês de Sapucaí, uma forte chuva caiu na cidade e alagou Padre Miguel, destruindo, de forma catastrófica, boa parte do bairro.
}

Rev. Eletrônica Mestr. Educ. Ambient. Rio Grande, Dossiê temático "Imagens: resistências e criações cotidianas", p.327-346, jun. 2020. E-ISSN 1517-1256 
atrás, apenas, da Beija-Flor de Nilópolis. Ela não cantou, apenas recitou os versos da canção. Aquelas palavras ecoaram no estúdio. À ela pertenciam, emanavam de seu corpo:

Não sou escravo de nenhum senhor
Meu Paraíso é meu bastião
Meu Tuiuti, o quilombo da favela
É sentinela na libertação

Meu nome é Cátia Cilene de Paula tenho 50 anos.

Se eu soubesse que fazer 50 anos era tão bom, eu teria feito um tempo atrás, como se fosse possível. (risos).

Sou professora hoje da rede municipal do Rio de Janeiro, mas nem sempre foi assim. Trabalhei em muitas coisas. Até que em 2005 por diversas circunstancias, consegui terminar o curso de pedagogia e fui trabalhar no Liceu de Artes e Ofícios. Que para mim foi maravilhoso. Ao mesmo tempo que foi meu céu e também meu inferno. Porque ali, no primeiro dia que eu cheguei, foi a primeira vez que eu me deparei com a questão racial num ambiente de trabalho. Porque até então...eu trabalhei em fábrica, lojas, e nunca senti tão de perto. Eu morava no Jacaré e quando fui entrevistada, antes da entrevista, a pessoa que ia me entrevistar, mandou um recado para mim pedindo que eu não fosse vestida de shortinho e top. Aí eu fiquei pensando: gente, eu sou uma professora, vou para uma entrevista de short e top? Mas aí tudo bem, passou. Comecei a trabalhar, fiquei lá por alguns anos. Até que passei para o concurso da prefeitura e finalmente realizar meu desejo que era ser professora da rede municipal do Rio de Janeiro. Lidar com crianças que eram exatamente como eu fui. Pobre, nascida numa comunidade. Comunidade não, numa favela mesmo. Comunidade é amenizar uma coisa que não é tão fácil. Eu sou muito feliz com isso. Mas o fato de eu ser feliz com isso não significa que é sempre tudo muito perfeito. Tudo muito tranquilo. [...]

Eu mesma estudei nos anos 80 e não tive uma professora negra. Hoje, graças a Deus, têm várias. Mas eu agradeço muito tambémas políticas de ação afirmativa que possibilitaram que muitos negros chegassem até a universidade. [...] Eu tenho uma sobrinha que foi morar na minha casa quando tinha sete anos. E morou comigo até crescer. Ela falou que a maioria dos professores ensinava e quando ela chegava em casa dizia: tia, quando eu crescer eu hei de ser branca do olho azul. Ela achava que quando crescesse ela iria mudar de cor. Porque as professoras dela eram todas assim. Hoje a gente tem uma representatividade muito grande. E não só da negra como eu que não quero alisar cabelo, não quero alisar nada, meu cabelo é esse, vai ficar assim, pronto e acabou. Mas também como outras que têm por opção, pode ser por facilidade ou por se ver melhor assim, cabelo alisado, trançado, esticado. Eu acho que a pessoaficar engessado em um determinado padrão não dá. É ter liberdade de se ver da melhor maneira possível, como ela se vê melhor.

Eu sou muito feliz. Muito feliz. Por tudo. Vida. Dificuldades não faltam. Mas mesmo assim a possibilidade sempre de recomeço, de tentar de

\footnotetext{
${ }^{6}$ Em 2018, o G.R.E.S. Paraíso do Tuiuti, com sede no bairro de São Cristóvão, na Zona Norte do Rio de Janeiro, levou para a avenida da Marquês de Sapucaí o samba-enredo "Meu Deus, Meu Deus, Está Extinta a Escravidão?" que questionava os 130 anos da abolição da escravidão do povo negro no Brasil.
}

Rev. Eletrônica Mestr. Educ. Ambient. Rio Grande, Dossiê temático "Imagens: resistências e criações cotidianas", p.327-346, jun. 2020. E-ISSN 1517-1256 
novo. Eu sou meio Poliana, sabe? Acho que no fim tudo fica bem. Sempre acredito nisso.

Isso aqui é tudo o que eu sou... (segurando os ursinhos de pelúcia que trouxe para o ensaio) eu adoro meus bichinhos... (Cátia abraça as plumas azuis, parte de sua fantasia de carnaval) O Tuiuti que eu amo. (referindose à sua escola de samba do coração).

Cátia não quer voltar no tempo, está amando fazer 50 anos e quer ser a professora negra que não teve em sua infância, período esse que traz representadopor seus bichos de pelúcia. Quer que as crianças da comunidade (ou favela) como ela mesmo afirma, tenham uma ou várias professoras negras para que se sintam representadas, para que possam se espelharem por aspectos incomuns que as identificam. A antiga moradora do bairro do Jacaré (subúrbio da cidade do Rio de Janeiro) almejou ser a professora de crianças de outras comunidades para ser dentre outras coisas, seu espelho. A estética do cabelo também aparece em sua fala, como afirmação, beleza e liberdade. Cátia afirma-se como a professora, mulher, negra que se colocacontra as amarras dos padrões e traz nos versos do samba da Tuiuti os lemas da sua existência.

\section{Diga, espelho meu}

Trouxemos a metáfora do espelho para este texto para falar de nossa pesquisa e de resistências possíveis, apresentando aqui apenas uma parte, um recorte daquilo que estamos desenvolvendo. Até o momento, dezesseis professoras aceitaram nosso convite para conversar e, junto com elas, produzir nossos ensaios fotográficos e videográficos. Entre essas mulheres, algumas se enunciam negras, outras como lésbicas, algumas como transgênero. Ainda há muito o que pensar e conversar, entretanto, optamos por fazer esta seleção pela relação direta e indireta destas mulheres com o carnaval carioca, seja por sua participação ativa ou pela história de resistência do próprio carnaval.

Hoje, televisionado para mais de 200 países, na TV ou pela Internet, o carnaval da cidade maravilhosa possui grande cobertura. É a maior festa popular da humanidade. Uma explosão de cores e alegria, mas não é só isso. Hoje, o que a gente vê na Marquês de Sapucaí, são escolas de samba que trazem para o carnaval temas e críticas sociais antenadas com seu tempo, delatando, em forma de apresentação/representação, as mazelas, a violência, a dor de um povo. Um povo que, naquele 'espaçotempo' da Sapucaí, não apenas denuncia violências como, também, ressignifica o passado, desafiando a "história oficial” e, num ato de coragem explícita, apresenta seu ponto de vista da narrativa história. 
Este foi o caso da G.R.E.S. Estação Primeira de Mangueira que,em 2019, foi campeã com o samba-enredo História Pra Ninar Gente Grande:

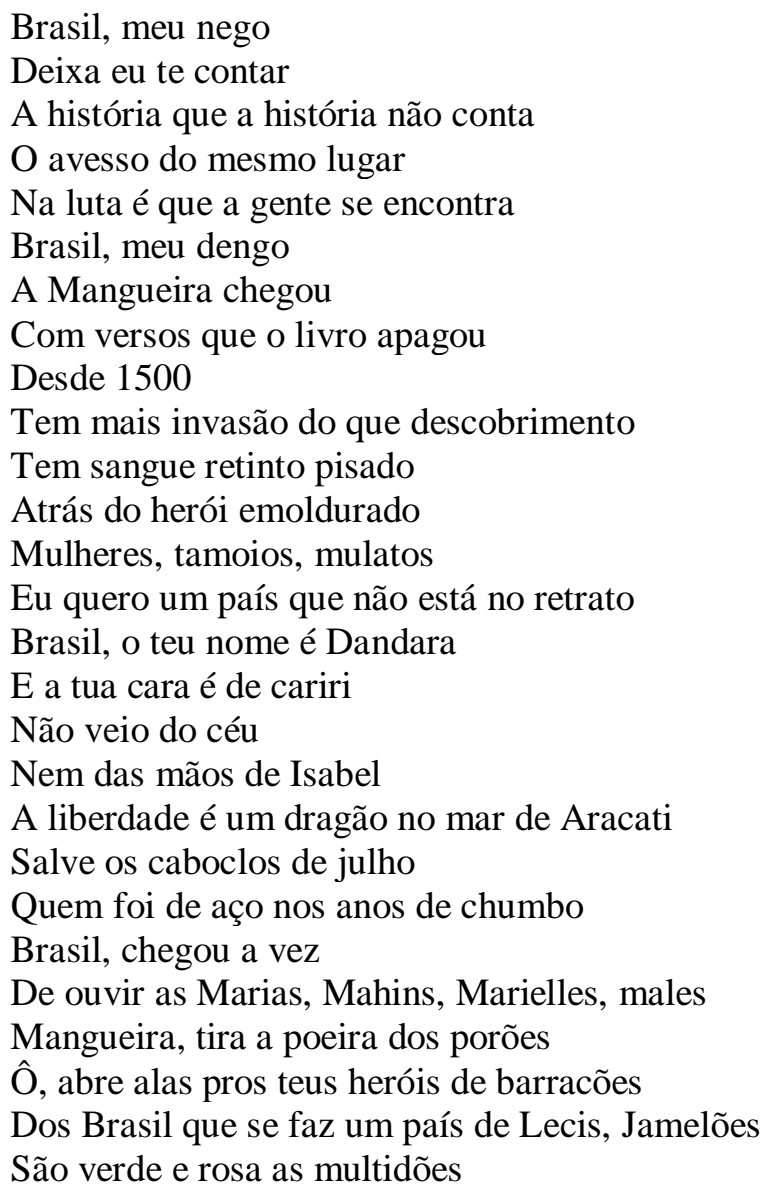

Durante 65 minutos, como em um filme, a Mangueira desfilou contando sua história em sequência, feito o fluxo de um rio, como na tecnologia streaming de dados da internet. $\mathrm{O}$ acontecimento do desfile na Sapucaí precisa seguir o enredo para contar sua história, assim como um filme precisa seguir o roteiro para dar conta de uma narrativa. Cada ala, cada carro alegórico, é uma parte da história a ser contada. O que é um filme senão um aglomerado de sequências inseridas em um tempo/duração? O desfile de uma escola de samba também tem esta similaridade com o audiovisual: o tempo/duração de uma história. É a verdade do cinema (DELEUZE, 1985). É a verdade do carnaval.

Não vamos aqui fazer uma análise completa do samba da Mangueira e seus significados, mas dentre elas destaca-se a figura de Marielle Franco, mulher, feminista, bissexual, negra, da favela da Maré, eleita democraticamente para ocupar a cadeira de vereadora da Câmara de Vereadores da cidade do Rio de Janeiro, que foi executada a tiros no Estácio, região central da cidade, após sair de um evento na Lapa chamadoJovens 
Negras Movendo as Estruturas, em 14 de março de 2018. Neste 14 de março de 2020, dois anos após seu assassinato, a pergunta persiste: quem mandou matar Marielle? O caso, ainda sem solução, segue aberto, como uma ferida exposta. Entretanto, e apesar de toda a dor, no desfile que homenageava Marielle, lá estava sua viúva, Mônica Benício, em menos de um ano após sua morte. Como isso é possível? Que força é essa? Como a dor pode ser convertida em alegria?

Para melhor entendermos como se dão estes processos de resistência, buscamos algumas pistas na tese de José Valter Pereira, mais conhecido como Valter Filé. A tese, orientada por Nilda Alves, O que espanta miséria é festa! Puxando conversa: narrativas e memórias nas redes educativas do samba, parte da pesquisa do projeto Puxando Conversa, que de 1990 a 2004, "registrou em vídeo e exibiu, em locais públicos, aspectos da vida e da obra de 49 compositores de samba do Estado do Rio de Janeiro" (FILÉ, 2006, p. 4) e que nos faz compreender, pelas memórias de seus depoentes e as análises do pesquisador, a história de resistência do próprio samba.

Histórias de tantos compositores que nos mostram as formas como estabelecem suas maneiras cotidianas de estar no mundo, a solidariedade, as contradições, a moral, as tragédias e as festas. Os "golpes", as "malandragens", a dura realidade desta gente e as maneiras que encontram para sobreviver, tanto financeira quanto emocionalmente.

Formas descritas pelos compositores que, com suas obras, registram desde as iniciativas governamentais até o dia-a-dia destas populações, suas condições materiais de vida, seus valores e seus amores.

O samba é uma tradição, sem dúvida, mas a marca desta tradição sempre foi a mudança, a reinvenção, para incorporar novos temas, para pensar novos problemas, para continuar suas narrativas, para continuar o diálogo com o mundo (Alvito, op. cit.). É nesse diálogo do samba com o mundo que o 'Puxando Conversa' se insere. Além de contribuir com a "rearticulação" do samba, o projeto está construindo um acervo audiovisual de fundamental importância para compreendermos melhor a riqueza do nosso patrimônio artístico-cultural musical e suas redes de significados. (FILÉ, 2006, p. 44)

Mas é preciso voltar um pouco mais no tempo para melhor compreendermos esta história e tocar na ferida da escravidão, tema recorrente em todo carnaval, uma questão que, segundo o autor,

[...]traz um diagnóstico que dá conta do nosso fracasso como nação, certamente tomando como referência a Europa. Esse fracasso inclui nosso componente cultural, marcadamente atulhado, principalmente, de negros e de índios, embora estes últimos tivessem presenças mais discretas e pudessem ser "confinados" a determinados espaçostempos. A escravidão

Rev. Eletrônica Mestr. Educ. Ambient. Rio Grande, Dossiê temático "Imagens: resistências e criações cotidianas", p.327-346, jun. 2020. E-ISSN 1517-1256 
era/é o nosso mal-estar civilizatório. [...] Entre as tentativas de regeneração desse nosso "desastre", estão as providências de se adotar mão-de-obra estrangeira. Gente "adequada" para dar novos "toques" à nossa constituição, ao desenvolvimento de uma produção mais qualificada e de quebra, segundo as teorias eugenistas, poderiam dar conta de uma miscigenação que pudesse "embranquecer" o país. [...] A busca da nossa identidade é, então, antes de mais nada, um exame médico para descobrir nossas moléstias e curá-las. É bem verdade que, de antemão, já se sabia do que padecíamos. Negros e mestiços davam visibilidade a esta moléstia. Vêlos na paisagem urbana já era um desagrado, pior ainda era aturar suas algazarras, suas formas de cultura.(FILÉ, 2006, p. 50)

Exposta a ferida, após a assinatura da Lei Áurea pela Princesa Isabel, heroína da história oficial, mas questionada pelo samba-enredo da Mangueira de 2019, cuja lei aboliu a escravidão no Brasil,vieram os movimentos eugenistas, tentativas de embranquecimento dos brasileiros. Tão logo os negros ganharam a liberdade, trabalhadores italianos foram “importados”. Disso, todos nós já sabemos. Entretanto, as tentativas de um apagamento, tanto do período da escravidão quanto dos próprios negros, não parou por aí. Num segundo movimento, a mestiçagem ganha destaque.

A "mistura", neste sentido, vai sendo pensada na transição de um problema para uma solução. A mestiçagem vai servir, principalmente no governo Vargas, como modelo ou exemplo de convivência que vai encontrar no samba sua consolidação. $O$ samba que se espera capaz de produzir sentimentos de nacionalidade. Essa empreitada foi favorecida pela implantação da indústria cultural - rádio e disco, tendo a Rádio Nacional desempenhado o papel de "integração nacional”. (FILÉ, 2006, p. 52)

O propósito de uma identidade nacional era promover uma estabilidade, uma coesão, um pacto de estabilidade e neutralização das diferenças. "Pacto que permitiria a superação das regionalidades, contraditoriamente, com o apagamento das diferenças, com o silenciamento dos 'derrotados'." (FILÉ, 2006, p. 51). Um pacto em prol de uma identidade nacional fabulada onde o samba possibilitaria esta integração e apagamentos de nossas diferenças. Entretanto, apesar da aceitação do samba como ícone de integração nacional e impulsionado pela indústria cultural, em parte, não deu certo.

Mas se o samba, como gênero musical, foi aceito como ícone da cultura brasileira, como agente catalisador de uma suposta essência nacional, ele mesmo sempre esteve carregado de contradições, principalmente pela capacidade de aglutinar as diferenças sem reduzi-las.

Ao samba acorreram gente dos vários cantos do país, adotando-lhe como sentimento, mas ampliando-lhe a complexidade. Do gaúcho Lupicínio Rodrigues ao ítalo-paulista Adoniran Barbosa, do baiano Riachão 
passando por Cartola e Nego Fugão, o mesmo samba cruza o país levando consigo os desejos contraditórios de uma identidade nacional homogênea. Contradição da sua própria condição como cultura negra numa sociedade que não vê o negro como cidadão e sim como exescravo ou um objeto metafísico sub ou supervalorizado, o que dá no mesmo, no sentido de sua não existência como pessoa com história. Condição paradoxal que faz com que o samba "entre" em certos lugares, mesmo que, em alguns, como coisa "popular", portanto exótica, ou quando precisamos mostrar nosso "folclore" a algum estrangeiro. $\mathrm{O}$ samba entra em muitos "lugares" como produto cultural simbólico, como produto de mercado desvinculado das suas referências, das gentes e das maneiras de viver dessa gente que lhe dá vida. O samba entra em muitos salões elegantes, mas o negão compositor, muitas vezes, fica do lado de fora ou, quando entra, vira o popular que dá o toque de autenticidade como requisito fundamental a determinados gostos intelectuais. (FILÉ, 2006, p. 52)

O projeto de integração nacional a partir da invenção de uma identidade nacional fracassou. $\mathrm{O}$ racismo estrutural do Brasil emperrou as engrenagens. $\mathrm{O}$ carnaval e sua potência do falso ainda possuía os elementos necessários para promover a inversão/transformação.

Em tom de deboche, mas levando muito a sério, o carnaval foi se organizando com o tempo. Não vamos aqui levantar questões histórias, mas sim fazer um apanhado de indícios que, em nossa percepção, faz-nos entender o carnaval das escolas de samba da cidade do Rio de Janeiro como um movimento social de resistência, em especial, da população negra.

A criação de uma hierarquia, dentro das escolas de samba, nos remete aos títulos monárquicos europeus e à nobreza da corte. São eles: rainha de bateria, mestre de bateria, mestre-sala e porta-bandeira, princesa do carnaval... Tais personagens têm função social definida 'dentrofora' das escolas de samba, seja em prol do carnaval, seja em prol da comunidade.A ironia do uso dos títulos burgueses, operando na comunidade, promovem ações com senso de responsabilidade. A cada título associa-se um conjunto de ações que são praticadas e movimentam uma rede de conhecimentos que promovem saberes sobre a escola, a comunidade e o próprio samba. Ações estas que não apenas podem garantir a nota dez na apuração do carnaval, mas também o bem estar da comunidade.

E foi brincando entre reis, rainhas, mestres e princesas que surgiram os projetos sociais, tais como, Mangueira do Amanhã e Império do futuro, são escolas de samba mirins que, para participar, é preciso que a criança esteja matriculada na escola. É a criança da escola na escola da escola, ou seja, é a criança da comunidade que tem uma escola de samba que, para frequentar o projeto social da escola de samba da comunidade precisa 
estar matriculada na escola onde circulam os 'saberesfazeres' institucionalizados, organizado pelo poder público. Os currículos, então, se misturam. Tais iniciativas nos levam a acreditar que, se não fossem os projetos sociais, se não fosse pela organização em escolas de samba, se não fosse através samba, estas populações continuariam invisibilizadas, descartadas, oprimidas.

O desfile das escolas de samba do grupo especial é hoje uma grande tela, ao vivo, à distância, em cores, uma janela, um 'espaçotempo' de criação, narrativas, denúncia, crítica, deboche, história, ironia, fabulação do real no real. Pura fantasia!

O povo negro nos ensinou/ensina que a luta é nos/dos/com os cotidianos. Que as dores são muitas. Mas, acima de tudo, nos ensinou/ensina a resistir com felicidade. Porque nada pode ser mais subversivo que a alegria. Pois, como diz a letra do samba,

\author{
Acredito ser o mais valente \\ Nesta luta do rochedo com o mar \\ (E com o mar) \\ É hoje o dia da alegria e a tristeza \\ Nem pode pensar em chegar \\ Diga espelho meu \\ Se há na avenida \\ Alguém mais feliz que eu
}

\title{
Referências
}

ALVES, Nilda. Tecer conhecimentos em rede. In: ALVES, N. \& GARCIA, R. L. (org.). O sentido da Escola. Petrópolis, RJ: DP et Alii, 2008.

ANDRADE, Nívea et al. Os movimentos necessários às pesquisas com os cotidianos após muitas 'conversas' acerca deles. In: OLIVEIRA, Inês Barbosa de; PEIXOTO, Leonardo Ferreira; SÜSSEKIND, Maria Maria Luiza (org.) Estudos do cotidiano, currículo e formação docente:questões metodológicas, políticas e epistemológicas. Curitiba: CRV, 2019.

ANDRADE, Nívea et al. Redes Educativas 'dentrofora' das escolas, exemplificadas pela formação de professores. In: SANTOS, Lucíola, DALBEN, Ângela e LEAL, Júlio Diniz Leiva (Orgs.). Convergências e tensões no campo da formação e do trabalho docente: Currículo, Ensino de Educação Física, Ensino de Geografia, Ensino de História, Escola, Família e Comunidade. 66 ed. Belo Horizonte/MG: Autêntica, 2010.

BUTLER, Judith. Quadros de guerra: quando a vida é passível de luto? Rio de Janeiro: Civilização Brasileira, 2018.

DELEUZE, Gilles. A imagem-tempo. São Paulo: Brasiliense, 1985. 
Dicionário da TV Gobo. v.1: programas de dramaturgia \& entretenimento / Projeto Memórias das Organizações Globo. Rio de Janeiro: Jorge Zahar Ed., 2003.

CERTEAU,Michel de. História e psicanálise: entre ciência e ficção. Belo horizonte: Autêntica, 2011.

CERTEAU, Michel de. A invenção do cotidiano: 1 . Artes de fazer. Petrópolis, RJ: Vozes, 2014.

CERTEAU, Michel de; GIARD, Luce; MAYOL, Pierre. A invenção do cotidiano: 2. morar, cozinhar. Petrópolis, RJ: Vozes, 2013.

KASTRUP, Virgínia. Políticas cognitivas na formação do professor e o problema do devir-mestre. Revista Educação \& Sociedade, Campinas, vol. 26, n. 93, p. 1273-1288, Set./Dez. 2005.

KASTRUP, Virgínia. A Invenção de si e do mundo. Belo Horizonte: Autêntica, 2007.

KILPP, Suzana. Dispersão-convergência: apontamentos para a pesquisa de audiovisualidades. In: MONTAÑO, Sonia; FISCHER, Gustavo: KILPP, Suzana. Impacto das novas mídias no estatuto da imagem. Porto Alegre: Sulina, 2012.

MARQUES, Davida. Entre fabulações de uma formação docente. Revista Digital do LAV, v. 8, n. 2, p. 160-174, 2015. Disponível em:

http://dx.doi.org/10.5902/1983734819870. Acesso em: 16 jul. 2019.

NOLASCO-SILVA, Leonardo et al. A invenção de si, do outro e da diferença sexual nas telas do YouTube: sexo e gênero como práticas culturais. In: FILHO, Aldo Victorio; BERINO, Aristóstoles; SOARES, Maria da Conceição Silva (org.) Educação e audiovisualidades. Curitiba: Appris, 2018.

PEREIRA, José Valter (Valter Filé). O que espanta a míséria é festa! Puxando Conversa: narrativas e memórias nas redes educativas do samba. Tese de doutorado defendida em 2006.

PRECIADO, Beatriz. Manifesto Contrassexual: práticas subversivas de identidade sexual. São Paulo: n-1 Edições, 2014.

PRECIADO, Beatriz. Testo Junkie: sexo, drogas e biopolítica na era farmacopornográfica. São Paulo: n-1 edições, 2018.

WULF, Christoph. Homo Pictor: imaginação, ritual e aprendizado mimético no mundo globalizado. São Paulo: Hedra, 2013.

Submetido em: 30-04-2020.

Publicado em: 01-07-2020. 